\title{
MANAJEMEN PELAKSANAAN MODIFIKASI RPP PADA SEKOLAH INKLUSI SDN SEMANGAT DALAM 2 BANJARMASIN
}

\author{
Annisa Raudatul Jannah \\ Program Studi Pendidikan Khusus, FKIP, Universitas Lambung Mangkurat \\ annisaraudatul08@gmail.com \\ Rahmah Milinia Sari \\ Program Studi Pendidikan Khusus, FKIP, Universitas Lambung Mangkurat \\ rahmahmiliniasari@gmail.com \\ Indah Putri Pratiwi \\ Program Studi Pendidikan Khusus, FKIP, Universitas Lambung Mangkurat \\ indahput0506@gmail.com \\ Yeni Aprilia Ningrum \\ Program Studi Pendidikan Khusus, FKIP, Universitas Lambung Mangkurat \\ yeni.aprilia2704@gmail.com
}

\begin{abstract}
ABSTRAK
Manajemen pendidikan di sekolah inklusi merupakan proses pengaturan dan pengelolaan sumber daya dalam menyelenggarakan sekolah inklusi yang meliputi perencanaan, pelaksanaan, pengawasan, berkaitan dengan tujuan, efektifitas, serta efisensi penyelenggaraan sistem pendidikan bagi seluruh siswa tanpa terkecuali. Dalam perencanaan pembelajaran yang dibuat oleh guru di sekolah sebelum melaksanakan proses pembelajaran, yang lebih dikenal dengan istilah RPP (Rencana Pelaksanaan Pembelajaran) adalah pegangan seorang guru dalam mengajar di dalam kelas yang membantunya agar sesuai dengan Standar Kompetensi dan Kompetensi Dasar. Kemudian di sekolah inklusi, modifikasi RPP sangat diharuskan karena menyesuaikan dengan kondisi siswa berkebutuhan khusus (ABK) yang di susun dan dikembangkan oleh


pendidik yang menjadi pedoman pendidik dalam melaksanakan tahapan pembelajaran baik secara teori maupun praktek. Sehingga sasaran yang di tujukan pada pembelajaran ini yaitu modifikasi RPP untuk anak berkebutuhan khusus (ABK) yang membutukan strategi pembelajaran tersendiri sesuai dengan kondisi, kebutuhan dan potensi anak. Dalam penelitian ini bertujuan untuk mengetahui bagaimana proses penyusunan RPP untuk anak berkebutuhan khusus (ABK) yang telah dimodifikasi sedemikian rupa untuk membantu dalam proses pembelajaran anak. Adapun metode penelitian yang digunakan yaitu penelitian deskriptif yang bertujuan untuk mengetahui dan memaparkan secara jelas dan rinci manajemen modifikasi RPP dan pembelajaran pendidikan inklusi pada anak berkebutuhan khusus (ABK) di sekolah SDN Semangat Dalam 2 Banjarmasin. Berdasarkan hasil penelitian menunjukkan: 1) Salah satu langkah dalam modifikasi RPP, sekolah menggunakan cara tersendiri dengan membuat tim khusus dalam memodifikasi RPP yang terdiri dari para GPK dan guru mata pelajaran tertentu. 2) Faktor pendukungnya meliputi pengalaman profesional guru, kemampuan guru dalam mengembangkan program tahunan dan semesteran, dan tersedianya media pendukung. 3) Faktor penghambatnya meliputi alokasi waktu, sarana dan prasarana, terkendala oleh guru karena dalam implementasi RPP guru dituntut untuk lebih dapat memahami dan menyesuaikan diri terhadap anak, dan kesalahan pola asuh orangtua.

Kata Kunci :Manajemen, Modifikasi, RPP,PendidikanInklusif 


\section{PENDAHULUAN}

\section{Pendidikan Inklusif}

Sekolah memiliki peran yang sangat penting. Sekolah tidak hanya sebagai wahana untuk mencari ilmu pengetahuan saja, tetapi juga sebagai tempat yang dapat memberi bekal keterampilan untuk hidup yang nanti diharapkan dapat bermanfaat di dalam masyarakat. Di sekolah anak juga dibimbing untuk bersosialisasi dengan orang lain. Keberadaan sekolah tidak saja penting bagi anak normal, melainkan bermanfaat pula untuk anak berkebutuhan khusus yang memiliki keterbatasan dan kekurangan ketika harus berinteraksi dengan orang lain.

Anak berkebutuhan khusus dianggap sebagai sosok yang tidak berdaya dan perlu dikasihani. Hal inilah yang menjadikan anak berkebutuhan khusus sering dikucilkan atau termaginalkan dari lingkungan sekitar. Anak-anak berkebutuhan khusus sering menerima perlakuan yang diskriminatif dari orang lain. Bahkan untuk menerima pendidikan saja mereka sulit. Beberapa sekolah regular tidak mau menerima mereka sebagai siswa. Alasannya guru di sekolah tersebut tidak memiliki kualifikasi yang memadai untuk membimbing anak berkebutuhan khusus. Terkadang sekolah khusus letaknya jauh dari rumah mereka, sehingga banyak anak berkebutuhan khusus yang tidak mengenyam pendidikan (Pratiwi, 2015: 237).

Dalam mengatasi permasalahan tersebut, perlu disediakan berbagai layanan pendidikan atau sekolah bagi anak berkebutuhan khusus, baik menyangkut system pembelajaran, fasilitas yang mendukung, maupun peran guru yang sangat penting untuk memberikan motivasi dan arahan yang bersifat membangun. Sekolah yang dianggap tepat untuk anak berkebutuhan khusus adalah sekolah inklusi. Sekolah inklusi adalah sekolah regular yang disesuaikan dengan kebutuhan anak yang memiliki kelainan dan memiliki potensi kecerdasan dan bakat istimewa pada satu kesatuan yang sistemik (Ilahi, 2013: 25, dalam Pratiwi, 2015: 237).

Konsep pendidikan inklusif bertujuan untuk memasukkan anakanak penyandang cacat ke dalam kelas reguler dimana guru harus menggunakan berbagai pendekatan 
pengajaran, bekerja secara kolaboratif, dan menggunakan berbagai metode penilaian. Keberhasilan penerapan pendidikan inklusif bergantung pada keberadaan sistem pendukung, yang meliputi pelatihan guru, sumber daya untuk sekolah, dukungan sosial, dan partisipasi masyarakat, di antaranya dengan mengembangkan hubungan kolaboratif di antara staf dan

dengan orang tua, serta hubungan kolaboratif dengan organisasi yang terlibat dalam masyarakat (Rouse, 2007 ; Kantavong, 2017).

Guru dan staf sekolah memiliki peran penting bagi keberhasilan implementasi dan keberlanjutan pendidikan inklusif. Orang tua dan masyarakat juga berperan penting untuk memfasilitasi pendidikan inklusif yang sukses. Pendidikan inklusif tidak dapat bekerja sendiri, dan pendidikan umum yang mengambil peran utama dalam pendidikan inklusif perlu didukung para pemangku kepentingan: kepala sekolah, guru, orang tua, masyarakat, pemerintah dan sebagainya. Pelatihan yang sesuai untuk kepala sekolah, guru, dan asisten guru sangat diperlukan (Forlin 2012;
Sharma, Forlin, Deppeler \& Yang, 2013).

Pelaksanaan pendidikan inklusif seringkali menghadapi kendala karena sifatnya yang kompleks. Terlebih lagi, sebagai hasil dari Konferensi Dunia 1990 tentang pendidikan untuk semua, pendidikan inklusif telah mendapatkan definisi yang jauh lebih luas dalam dua dekade terakhir. Pendidikan inklusif mencakup juga penempatan siswa penyandang cacat, siswa dengan kesulitan belajar, dan kelompok marginal lainnya ke sekolah biasa Pendidikan inklusif juga mengatur hak semua peserta didik dengan beragam kebutuhan untuk mengakses pendidikan di sekolah pilihan mereka. Pelatihan untuk mempersiapkan guru bagi pendidikan inklusif merupakan faktor penting dalam memperbaiki sikap dan mendorong komitmen yang lebih besar bagi pendidikan inklusif. Menurut Forlin, ketika guru tidak dibekali dengan baik untuk menghadapi siswa SEN, mereka malah memiliki sikap negatif terhadap pendidikan inklusif. (Ainscow \& Haile Giorgis, 1999 ; Forlin, 2010).

Pendidikan inklusif di 
Indonesia diatur dalam UndangUndang Nomor 8 Tahun 2016 tentang Penyandang Disabilitas menggantikan UndangUndang Nomor 4 Tahun 1997 tentang Penyandang Cacat yang dipandang bersifat belas kasihan (charity based) dan belum berperspektif hak asasi manusia. Dalam peraturan yang lama, pemenuhan hak penyandang disabilitas masih dinilai sebagai masalah sosial. Penyandang disabilitas belum mendapatkan kesempatan untuk mengembangkan dirinya melalui kemandirian sebagai manusia yang bermartabat.

Di Indonesia, istilah 'pendidikan inklusif' mulai mendapatkan perhatian pada tahun 2001 ketika pemerintah memulai proyek percontohan tentang pendidikan inklusif (Nasichin,

2001). Indonesia secara resmi mengakui pendidikan inklusif ketika parlemen pada tahun 2003 mengeluarkan Undang-Undang Sistem Pendidikan Nasional, yang menetapkan bahwa semua warga negara dengan segala jenis disabilitas wajib untuk berpartisipasi dalam pendidikan inklusif. Pada tahun yang sama, pemerintah juga mengeluarkan keputusan tentang pendidikan inklusif untuk anak-anak dengan cacat kognitif dan fisik. Peraturan ini menetapkan bahwa pendidikan inklusif adalah pendidikan yang menjamin akses yang sama bagi siswa dengan segala jenis kecacatan untuk memperoleh pendidikan di sekolah umum bersama dengan siswa yang tidak cacat ( Sunardi, 2010).

Dalam Undang-Undang Nomor 8 Tahun 2016 Pasal 42 disebutkan bahwa pemerintah daerah wajib memfasilitasi pembentukan Unit Layanan Disabilitas untuk mendukung penyelenggaraan pendidikan inklusif tingkat dasar dan menengah. Unit Layanan Disabilitas memiliki fungsi antara lain meningkatkan kompetensi pendidik dan tenaga kependidikan di sekolah reguler dalam menangani peserta didik penyandang disabilitas; menyediakan pendampingan kepada peserta didik penyandang disabilitas untuk mendukung kelancaran proses pembelajaran; menyediakan media pembelajaran dan alat bantu yang diperlukan; menyediakan layanan konsultasi dan; mengembangkan kerja 
sama dengan pihak atau lembaga lain dalam upaya meningkatkan kualitas pendidikan untuk peserta didik penyandang disabilitas (Amka, 2019).

\section{Pengertian RPP}

Rencana pelaksanaan pembelajaran (RPP) adalah rencana yang menggambarkan prosedur dan pengorganisasian pembelajaran untuk mencapai satu kompetensi dasar yang ditetapkan dalam Standar Isi dan dijabarkan dalam silabus (Kunandar, 2011: 263).

Berdasarkan Peraturan Pemerintah Republik Indonesia Nomor 19 Tahun 2005 Pasal 20 dinyatakan bahwa "Perencanaan proses pembelajaran meliputi silabus dan rencana pembelajaran yang memuat sekurangkurangnya tujuan pembelajaran, sumber belajar, dan penilaian hasil belajar ". Menurut Permendiknas Nomor 41 Tahun 2007, komponen RPP adalah: Identitas mata pelajaran, standar kompetensi, kompetensi dasar, indikator pencapaian kompetensi, tujuan pembelajaran, materi ajar, alokasi waktu, metode pembelajaran, kegiatan pembelajaran, penilaian hasil belajar, dan sumber belajar.

\section{Tujuan dan Fungsi RPP}

Tujuan rencana pelaksanaan pembelajaran adalah untuk: (1) mempermudah, memperlancar dan meningkatkan hasil proses belajarmengajar; (2) dengan menyusun rencana pembelajaran secara profesional, sistematis dan berdaya guna, maka guru akan mampu melihat, mengamati, menganalisis, dan memprediksi program pembelajaran sebagai kerangka kerja yang logis dan terencana (Kunandar, 2011: 264).

Fungsi rencana pembelajaran adalah sebagai acuan bagi guru untuk melaksanakan kegiatan belajarmengajar (kegiatan pembelajaran) agar lebih terarah dan berjalan secara efektif dan efisien (Kunandar, 2011: 264).

\section{Unsur-Unsur yang Perlu}

\section{Diperhatikan dalam Penyusunan RPP}

Menurut (Kunandar, 2011: 265) menyebutkan bahwa ada beberapa unsur yang perlu diperhatikan dalam penyusunan RPP yaitu: 1) Mengacu pada kompetensi dan kemampuan dasar yang harus dikuasai siswa, serta materi dan submateri pembelajaran, pengalaman belajar yang telah 
dikembangkan di dalam silabus. 2) Menggunakan berbagai pendekatan yang sesuai dengan materi yang memberikan kecakapan hidup (life skills) sesuai dengan permasalahan dan lingkungan sehari-hari.

Menggunakan metode dan media yang sesuai, yang mendekatkan siswa dengan pengalaman langsung. 4) Penilaian dengan sistem pengujian menyeluruh dan berkelanjutan didasarkan pada sistem pengujian yang dikembangkan selaras dengan pengembangan silabus.

\section{Manajemen Modifikasi RPP}

Adapun manajemen modifikasi RPP terbagi menjadi beberapa langkah, dalam (Amka, 2020) memaparkan sebagai berikut:

\section{Perencanaan Modif RPP}

Satu-satunya hal yang pasti di masa depan dari organisasi apapun termasuk lembaga pendidikan adalah perubahan, dan perencanaan penting untuk menjembatani masa kini dan masa depan yang meningkatkan kemungkinan untuk mencapai hasil yang diinginkan. Mondy dan Premeaux (1995) menjelaskan bahwa perencanaan merupakan proses menentukan apa yang seharusnya dicapai dan bagaimana mewujudkannya dalam kenyataan. Perencanaan amat penting untuk implementasi strategi dan evaluasi strategi yang berhasil, terutama karena aktivitas pengorganisasian, pemotivasian, penunjukkan staff, dan pengendalian tergantung pada perencanaan yang baik (Fred R. David, 2004).

Dalam konteks lembaga pendidikan, untuk menyusun kegiatan lembaga pendidikan, diperlukan data yang banyak dan valid, pertimbangan dan pemikiran oleh sejumlah orang yang berkaitan dengan hal yang direncanakan. Oleh karena itu kegiatan perencanaan sebaiknya melibatkan setiap unsur lembaga pendidikan tersebut dalam rangka peningkatan mutu pendidikan.

2. Pengorganisasian Modif RPP

Tujuan pengorganisasian adalah mencapai usaha terkoordinasi dengan menerapkan tugas dan hubungan wewenang. Malayu S.P. Hasbuan (1995) mendifinisikan pengorganisasian sebagai suatu proses penentuan, pengelompokkan dan pengaturan bermacam-macam aktivitas yang diperlukan untuk mencapai tujuan, menempatkan orangorang pada setiap aktivitas ini, menyediakan alat-alat yang 
diperlukan, menetapkan wewenang yang secara relative didelegasikan kepada setiap individu yang akan melakukan aktivitasaktivitas tersebut. Pengorganisasian fungsi manajemen dapat dilihat terdiri dari tiga aktivitas berurutan: membagi-bagi tugas menjadi pekerjaan yang lebih sempit (spesialisasi pekerjaan), menggabungkan pekerjaan untuk membentuk departemen (departementalisasi), dan mendelegasikan wewenang (Fred R. David, 2004).

Dalam konteks pendidikan, pengorganisasian merupakan salah satu aktivitas manajerial yang juga menentukan berlangsungnya kegiatan kependidikan sebagaimana yang diharapkan. Lembaga pendidikan sebagai suatu organisasi memiliki berbagai unsur yang terpadu dalam suatu sistem yang harus terorganisir secara rapih dan tepat, baik tujuan, personil, manajemen, teknologi, siswa/member, kurikulum, uang, metode, fasilitas, dan faktor luar seperti masyarakat dan lingkungan sosial budaya.

Sutisna (1985) mengemukakan bahwa organisasi yang baik senantiasa mempunyai dan menggunakan tujuan, kewenangan, dan pengetahuan dalam melakukan pekerjaan-pekerjaan.
Dalam organisasi yang baik semua bagiannya bekerja dalam keselarasan seakan-akan menjadi sebagian dari keseluruhan yang tak terpisahkan. Semua itu baru dapat dicapai oleh organisasi pendidikan, manakala dilakukan upaya: 1) Menyusun struktur kelembagaan, Mengembangkan prosedur yang berlaku, 3) Menentukan persyaratan bagi instruktur dan karyawan yang diterima, 4) Membagi sumber daya instruktur dan karyawan yang ada dalam pekerjaan.

\section{Pelaksanaan Modif RPP}

Dalam konteks lembaga pendidikan, kepemimpinan pada gilirannya bermuara pada pencapaian visi dan misi organisasi atau lembaga pendidikan yang dilihat dari mutu pembelajaran yang dicapai dengan sungguh-sungguh oleh semua personil lembaga pendidikan.

Soetopo dan Soemanto (1982) menjelaskan bahwa kepemimpinan pendidikan ialah kemampuan untuk mempengaruhi dan menggerakkan orang lain untuk mencapai tujuan pendidikan secara bebas dan sukarela. Di dalam kepemimpinan pendidikan sebagaimana dijalankan pimpinan harus dilandasi konsep demokratisasi, spesialisasi tugas, pendelegasian 
wewenang, profesionalitas dan integrasi tugas untuk mencapai tujuan bersama yaitu tujuan organisasi, tujuan individu dan tujuan pemimpinnya.

4. Pengawasan Modif RPP

Sebagaimana yang dikutif Muhammad Ismail Yusanto (2003), Mockler (1994) mendifinisikan pengawasan sebagai suatu upaya sistematis untuk menetapkan standar prestasi kerja dengan tujuan perencanaan untuk mendesain sistem umpan balik informasi; untuk membandingkan prestasi sesungguhnya dengan standar yang telah ditetapkan itu; menentukan apakah ada penyimpangan dan mengukur signifikansi penyimpangan tersebut; dan mengambil tindakan perbaikan yang diperlukan untuk menjamin bahwa semua sumberdaya perusahaan telah digunakan dengan cara yang paling efekif dan efisien guna tercapainya tujuan perusahaan.

Dalam konteks pendidikan, Depdiknas (1999) mengistilahkan pengawasan sebagai pengawasan program pengajaran dan pembelajaran atau supervisi yang harus diterapkan sebagai berikut:

a Pengawasan yang dilakukan pimpinan dengan memfokuskan pada usaha mengatasi hambatan yang dihadapi para instruktur atau staf dan tidak semata-mata mencari kesalahan.

b Bantuan dan bimbingan diberikan secara tidak langsung. Para staf diberikan dorongan untuk memperbaiki dirinya sendiri, sedangkan pimpinan hanya membantu.

c Pengawasan dalam bentuk saran yang efektif.

d Pengawasan yang dilakukan secara periodik.

\section{METODE PENELITIAN}

Dalam penelitian ini menggunakan metode penelitian deskriptif yang bertujuan untuk dapat mengetahui dan memaparkan secara jelas dan rinci menejemen modifikasi RRP dan pembelajaran pendidikan inklusi pada anak berkebutuhan khusus (ABK) di sekolah SDN Semangat Dalam 2 Banjarmasin. Oleh pendekatan tersebut memberikan kemungkinan untuk mendeskripsikan melalui pengamatan secara cermat, wawancara dengan informan kunci secara mendalam, sehingga keterkaitan aspek-aspek yang diteliti dapat digambarkan secara jelas. Dengan pendektan ini dimaksudkan agar terungkap data deskriptif dari informan baik lisan 
maupun tulisan tentang apa yang mereka lakukan, rasakan, dan mereka alami terhadap sewajarnya, cara kerja yang sistematis dan terarah serta dapat dipertanggung jawabkan sehingga tidak hilang sifat ilmiahnya.

1. Subyek Penelitian

Subjek dalam penelitian ini adalah guru SDN Semangat Dalam 2 yang berkaitan dengan modifikasi RRP.

2. Lokasi dan waktu penelitian

Lokasi dari penelitian ini peneliti mengambil tempat di SDN Semangat Dalam 2 Banjarmasin yang berlokasi di Jln. Melati Raya, Komp. Griya Pertama, Kec. Banjarmasin Timur.

3. Pelaksanaan Penelitian

Pelaksanaan penelitian dilakukan di SDN Semangat Dalam 2 yang dilaksanakan 1 hari pada tanggal 7 Maret 2020. Dalam pelaksanaan penelitian mencakup tentang subjek dari penelitian, lokasi, dan waktu penelitian. Peneliti juga mencatat berbagai temuan yang penting pada saat observasi yang digunakan untuk bahan dalam mengumpulkan data selama dilapangan.

4. Teknik Pengumpulan Data

Teknik pengumpulan data dalam penelitian ini menggunakan metode observasi, wawancara, dan dokumentasi yang dijelaskan sebagai berikut:

a. Observasi

Observasi adalah suatu cara pengumpulan data dengan pengamatan langsung dan pencatatan secara sistematis terhadap obyek yang akan diteliti. Observasi dilakukan oleh peneliti dengan cara pengamatan dan pencatatan mengenai pelaksanaan pembelajaran dikelas.

b. Wawancara

Wawancara adalah teknik pengumpulan data yang menggunakan tanya jawab melalui pertemuan dua orang atau lebih untuk bertukar informasi dan ide, sehingga dapat dikonstruksikan makna dalam suatu topik tertentu. Dalam penelitian ini menggunakan wawancara tidak struktur agar diperoleh data yang lebih mendalam. Selain itu, peneliti juga membuat pedoman wawancara secara garis besarnya disesuaikan dengan apa yang ingin ditanyakan. Selain mencatat proses dari wawancara yang berlangsung, peneliti juga menggunakan alat bantu rekam agar peneliti lebih mudah dalam mencerna hasil penelitian tersebut.

c. Dokumentasi

Dokumentasi adalah teknik pengumpulan data yang menggunakan catatan peristiwa yang sudah berlalu dalam bentuk tulisa, gambar, catatan, foto, video. Teknik pengumpulan data tersebut bertujuan sebagai data sekunder untuk mendapatkan data yang 
Jurnal Manajemen Pendidikan

FKIP Universitas Lambung Mangkurat

6 April 2020

sesuai dengan kebutuhan penelitian.

Data tersebut seperti gambar, foto, dokumen yang bisa dijadikan bukti bahwa peniliti benar-benar telah melakukan penelitian tentang Majemen Modifikasi RPP di sekolah yang menyelenggarakan pendidikan inklusi di SDN Semangat Dalam 2 Banjarmasin. 


\section{HASIL PENELITIAN DAN PEMBAHASAN}

\section{DataPokok}

Tabel 1. Jumlah Guru di Sekolah

\begin{tabular}{|c|c|}
\hline Guru Umum dan GPK & Jumlah Guru \\
\hline Umum & 27 orang \\
\hline GPK & 6 orang \\
\hline Total & 33 orang \\
\hline
\end{tabular}

Tabel 2. Jumlah Seluruh Siswa di Sekolah

\begin{tabular}{|c|c|}
\hline Siswa Reguler dan ABK & Jumlah siswa \\
\hline Reguler & 654 orang \\
\hline ABK & 27 orang \\
\hline Total & $\mathbf{6 8 1}$ orang \\
\hline
\end{tabular}

Tabel 3. Krakteristik Siswa ABK

\begin{tabular}{|c|c|}
\hline Jenis Ketunaan & Jumlah Siswa \\
\hline Autis Ringan & 2 orang \\
\hline Autis Sedang & 5 orang \\
\hline ADHD & 2 orang \\
\hline
\end{tabular}




\begin{tabular}{|c|c|}
\hline Tunagrahita Ringan & 5 orang \\
\hline Tunagrahita Sedang & 2 orang \\
\hline Tunagrahita Berat & 1 orang \\
\hline Tunarungu & 3 orang \\
\hline Lamban Belajar & 3 orang \\
\hline Tunaganda (ADHD, ATG) & 1 orang \\
\hline Slow Learner & 1 orang \\
\hline Disleksia & 1 orang \\
\hline Tunanetra (Low Vision) & 1 orang \\
\hline Total & $\mathbf{2 7}$ orang \\
\hline
\end{tabular}

\section{Perencanaan ModifikasiRPP}

a. TujuanPembelajaran

Berdasarkan dari hasil wawancara yang telah dilakukan, dari penjelasan yang telah disampaikan bahwa tujuan pembelajaran dirumuskan berdasarkan KD (kompetensi dasar) yang dapat diamati dan diukur. Kemudian tujuan pembelajaran ini memuat kemampuan atau kompetensi yang diharapkan dari peserta didik.

b. MateriPembelajaran

Berdasarkan dari hasil wawancara yang telah dilakukan, dari penjelasan yang telah disampaikan bahwa RPP yang disusun oleh guru mengacu kepada kurikulum 2013, yang mana dalam perencanaan RPP di modifikasi agar peserta didik anak berkebutuhan khusus dapat mengikuti kegiatan pembelajaran dengan materi yang telah dimodifikasi sedemikian rupa untuk ketercapaiannyakompetensi.

c. Penggunaan MetodePembelajaran Berdasarkan dari hasil wawancara yang telah dilakukan, dari penjelasan yang telah disampaikan bahwa penggunaan metode pembelajaran memiliki beberapa macam metode yang dilakukan sesuai dengan karakter dari anak tersebut seperti pemberian metode bimbingan penuh, praktek, dan ceramah.

d. Penilaian/Evaluasi 
berjalan di sekolah inklusif ataupun di sekolahkhusus.

\section{a. Identifikasi dan Asesmen Anak BerkebutuhanKhusus}

bahwa dalam penilaian hasil belajar anak menyesuaikan dengan kemampuan anak, misalnya saja anak yang tidak bisa membaca dan menulis maka evaluasi yang dilakukan guru yaitu dengan nilai praktek, perilaku respon terhadap perintah dan jika anak bisa membaca dan menulis, evaluasi yang dilakukan yaitu dengan menyesuaikan kemampuan anak yang mana yang mudah dipahamianak.

\section{Pelaksanaan Modifikasi RPP}

Proses pelaksanaan modifikasi RPP bukanlah hal yang mudah, karena akan bersentuhan dengan anak atau peserta didik yang kedudukannya sebagai objek yang dilayani. Dalam proses pelaksanaan ini identifikasi dan asesmen merupakan dasar dalam pembuatan RPP modifikasi ataupun PPI mengingat urgensi kedua hal tersebut, maka sekolah melaksanakan identifikasi dan asesmen tidak hanya sebagai formalitas biasa yang harus
Identifikasi adalah kegiatan untuk menemukenali kondisi anak yang sebenarnya. Identifikasi cermat agar tidak terjadi gkondisi objektif perilaku anak, sehingga dapat menentukan tindak lanjut yang tepat pula. Hal in sesuai dengan pendapat Budiyanto, et.all. (2013) yang mendefinisikan identifikasi sebagai suatu usaha untuk menemukenali anak berkebutuhan khusus, dalam hal ini anak atau peserta didik yang mengalami kelainan dengan berbagai gejalagejala yang menyertainya. Sementara asesmen merupakan rangkaian kegiatan mengumpulkan informasi tentang anak untuk dijadikan pertimbangan dalam pengambilan keputusan berbagai kegiatan yang mendukung pelayanan bagi peserta didiktersebut. perlu dilakukan dengan sangat penafsiran yang salah tentan 
Jurnal Manajemen Pendidikan

FKIP Universitas Lambung Mangkurat

6 April 2020

b. Pembuatan Profil Siswa Bagi Anak BerkebutuhanKhusus 
$$
\begin{aligned}
& 1 \\
& 1 \\
& 1 \\
& 1 \\
& 1 \\
& 1 \\
& 1 \\
& 1 \\
& 1 \\
& 1 \\
& 1 \\
& 1 \\
& 1 \\
& 1 \\
& 1 \\
& 1 \\
& 1 \\
& 1
\end{aligned}
$$

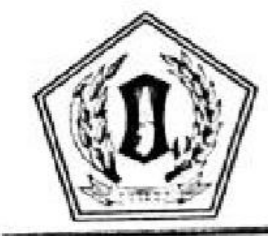

PEMERINTAH KABUPATEN BARITO KUALA DINAS PENDIDIKAN SEKOLAH DASAR NEGERI SEMANGAT DALAM 2 Jl. Melati Raya I RT. 16 Kel. Hdl Bakti Kec. Alalak Telp. (0511) 4310303

\section{DAFTAR NAMA ABK DAMPING SDN SEMANGAT DALAM 2 \\ KECAMATAN ALALAK KABUPATEN BARITO KUALA}

\begin{tabular}{|c|c|c|c|c|}
\hline No. & NАMA & TANGGAL LAHIR & KELAS & KETUNAAN \\
\hline 1. & $\begin{array}{l}\text { Muhammad Rafa Philip } \\
\text { Wong }\end{array}$ & Banjarmasin, 25 Juni 2012 & 1 & ADHD \\
\hline 2. & $\begin{array}{l}\text { Muhammad } \\
\text { Khalifaturrahman }\end{array}$ & Banjarmasin, 29 Desember 2009 & \multirow{5}{*}{2} & Autis Sedang \\
\hline 3. & Nur Ahmad Sudais & Banjarmasin, 29 Desember 2009 & & Autis Ringan \\
\hline 4. & Syakirah Izzati Salam & Banjarmasin, 15 Desember 2010 & & Autis Sedang \\
\hline 5. & Muhammad Hafiz & Banjarmasin, 22 Desember 2009 & & Autis Sedang \\
\hline$\frac{7 .}{8 .}$ & $\begin{array}{l}\text { M. Rakka Saputra } \\
\text { Verdy }\end{array}$ & Banjarmasin, 03 Oktober 2011 & & Tunagrahita \\
\hline$\frac{8 .}{9 .}$ & $\begin{array}{l}\text { Verdy } \\
\text { Kharis Barokatul Aulia }\end{array}$ & Banjarmasin, 9 januari 2010 & \multirow{7}{*}{3} & Tunarungu \\
\hline 10. & Kharis Barokatul Aulia & Banyu Wangi, 24 Februari 2010 & & Tunarungu \\
\hline 10. & M. Gilang & Pulau alalak, 20 september 2008 & & $\begin{array}{l}\text { Tunagrahita } \\
\text { ringan }\end{array}$ \\
\hline 11. & Saydina & Banjarmasin, 20 April 2010 & & Lamban belajar \\
\hline 12 . & Rizky Aufa. A. Asyam. S & Batola, 11Oktober 2010 & & $\begin{array}{l}\text { Tunaganda } \\
\text { (ADHD, ATG) }\end{array}$ \\
\hline 13. & M. Fathan Noor & Batola, 23 Juni 2010 & & Slow Learner \\
\hline 14. & Lukman Hakim & Gersik, 18 Maret 2009 & & Lamban belajar \\
\hline 15. & $\begin{array}{l}\text { Ahmad Sulthoni El } \\
\text { Hadrani }\end{array}$ & Banjarmasin, 16 Juli 2010 & \multirow{8}{*}{4} & Tunarungu \\
\hline 16. & Nazamul Ikhsan & Banjarmasin, 21 Desember 2009 & & $\begin{array}{l}\text { Tunagrahita } \\
\text { ringan }\end{array}$ \\
\hline 17. & Kiyona Murtissa & Marabahan, 19 Mei 2008 & & $\begin{array}{l}\text { Tunagrahita } \\
\text { ringan }\end{array}$ \\
\hline 18. & Kumala Sari & Banjarmasin, 12 April 2009 & & $\begin{array}{l}\text { Tunagrahita } \\
\text { ringan }\end{array}$ \\
\hline 19. & M. Noval Raihan & Banjarmasin, 09 November 2009 & & $\begin{array}{l}\text { Tunagrahita } \\
\text { Sedang }\end{array}$ \\
\hline 20. & Banyu Linatang Samudra & Kediri, 3 Oktober 2009 & & Autis sedang \\
\hline 21. & Rico Rastra Pratama & Banjarmasin, 18 Mei 2009 & & Autis Ringan \\
\hline 22. & Titole Baim & Banjarmasin, 17 oktober 2008 & & Disleksia \\
\hline 23. & M. Fahrizal & Pontianak, 8 Oktober 2008 & \multirow{2}{*}{5} & $\begin{array}{l}\text { Tunagrahita } \\
\text { Ringan }\end{array}$ \\
\hline 24. & Fitriyah & Batola, 14 Oktober 2004 & & $\begin{array}{l}\text { Tunagrahita } \\
\text { Sedang }\end{array}$ \\
\hline
\end{tabular}




\begin{tabular}{|c|c|c|c|c|c|}
\hline $\begin{array}{l}0 \\
7 \\
1 \\
1\end{array}$ & \multicolumn{5}{|c|}{$\begin{array}{l}\quad \text { PEMERINTAH KABUPATEN BARITO KUALA } \\
\text { DINAS PENDIDIKAN } \\
\text { SEKOLAH DASAR NEGERI SEMANGAT DALAM } 2 \\
\text { Jl. Melati Raya I RT. } 16 \text { Kel. Hdl Bakti Kec. Alalak Telp. }(0511) 4310303\end{array}$} \\
\hline \multirow[t]{3}{*}{1} & 25. & M. Rizky Syahbani & Banjarmasin, 29 Agustus 2008 & & Autis sedang \\
\hline & 26. & M. Akmal & Banjarmasin, 22 Januari 2009 & & Lamban belajar \\
\hline & 27. & Rajifa Azura & Banjarmasin, 19 April 2007 & 6 & $\begin{array}{l}\text { Tunanetra } \\
\text { (Low Vision) }\end{array}$ \\
\hline
\end{tabular}

Kepala SD Negeri Semangat Dalam 2

Kabupaten Batola

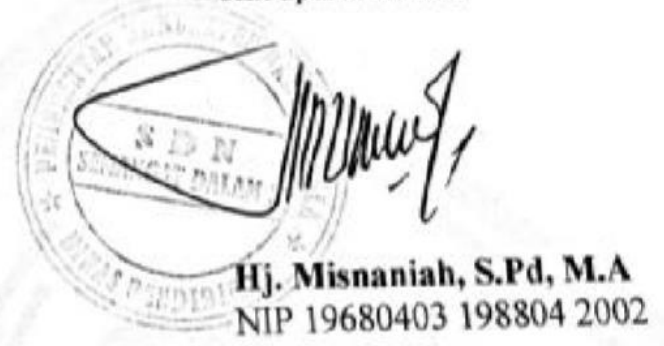


Pada dasarnya pembuatan profil ini berdasarkan pada kebutuhan pihak sekolah penyelenggara pendidikan untuk dapat memberikan layanan kepada setiap ABK sesuai dengan kekhususannya. Salah satu tujuan yang dilakukan sekolah dengan membuat dan mendokumentasikan seluruh catatan diri anak dalam suatu dokumen yaitu untuk dijadikan pedoman pada saat prencanaan modifikasi RPP.

\section{c. Perencanaan modifikasiRPP}

Salah satu langkah dalam memastikan bahwa RPP yang dimodifikasi sesuai dengan kekhususan peserta didik maka sekolah menggunakan cara tersendiri. Cara tersebut adalah dengan membuat tim khusus dalam memodifikasi RPP. Tim khusus ini terdiri dari para GPK dan guru pelajaran tertentu.

1) TujuanPembelajaran

Berdasarkan dari hasil
wawancara yang telah
dilakukan, dari penjelasan
yang telah disampaikan
bahwa tujuan pembelajaran
dirumuskan berdasarkan KD

(kompetensi dasar) yang dapat diamati dan diukur. Kemudian tujuan pembelajaran ini memuat kemampuan atau kompetensi yang diharapkan dari peserta didik.

2) MateriPembelajaran

Berdasarkan dari hasil wawancara yang telah dilakukan, dari penjelasan yang telah disampaikan bahwa RPP yang disusun oleh guru mengacu kepada kurikulum 2013, yang mana dalam perencanaan RPP di modifikasi agar peserta didik anak berkebutuhan khusus dapat mengikuti kegiatan pembelajaran dengan materi yang telah dimodifikasi sedemikian rupa untuk ketercapaiannya kompetensi.

3) Penggunaan MetodePembelajaran

Berdasarkan dari hasil wawancara yang telah dilakukan, dari penjelasan yang telah disampaikan bahwa penggunaan metode pembelajaran memiliki beberapa macam metode yang dilakukan sesuai dengan 
Jurnal Manajemen Pendidikan

FKIP Universitas Lambung Mangkurat

6 April 2020

karakter dari anak tersebut

seperti pemberian metode

bimbingan penuh, praktek,

dan ceramah.

4) Penilaian/Evaluasi

Berdasarkan dari hasil

wawancara yang telah

dilakukan, dari penjelasan

yang telah disampaikan

bahwa dalam penilaian hasil

belajar anak menyesuaikan

dengan kemampuan anak,

misalnya saja anak yang tidak

bisa membaca dan menulis

maka evaluasi yang dilakukan

guru yaitu dengan nilai

praktek, perilaku respon

terhadap 
1) Pengalaman profesionalguru

perintah dan jika anak bisa membaca dan

menulis, evaluasi yang dilakukan yaitu

dengan menyesuaikan kemampuan anak yang mana yang mudah dipahami anak.

\section{d. Evaluasi dalam Penerapan Pelaksanaan Modifikasi RPP}

Evaluasi dalam penerapan
pelaksaan modifikasi RPP di
sekolah inklusi dilakukan setiap
akhir semester. Dalam evaluasi ini
pihak sekolah mengadakan
evaluasi setiap akhir semester
dengan mengundang guru-guru.
Melalui evaluasi ini pula, sekolah
bermaksud mengumpulkan
masukan-masukan dan saran dari
guru, khususnya yang berkaitan
dengan pelaksanaan modifikasi
RPP menjadi PPI. Dalam evaluasi
ini juga bertujuan untuk
mengungkapkan
pelaksanaan yang telah berhasil
mencapai tujuan yang telah
ditetapkan.

\section{Faktor Pendukung dan Penghambat dalam Pelaksanaan ModifikasiRPP}

Adapun faktor pendukung dalam pelaksanaan Modifikasi Kurikulum, diantaranya:

\section{a. FaktorPendukung}

2) Kemampuan guru dalam mengembangkan program tahunan dan semester

3) Mengembangkan silabus dan modifikasi RPP serta menciptakan lingkungan yang kondusif dalam pelaksanaanpembelajaran

4) Tersedianya media pendukung misalnya melalui internet, guru dapat dengan mudah memahami RPP bernilai-nilai karakter dalam proses pembelajaran, sebagian besar guru yang sudah bisa membuat sendiri RPP bernilai-nilai karakter tidak segan untuk membantu guru yang belum memahami RPP bernilai-nilai berkarakterbangsa.

\section{b. FaktorPenghambat}

Menurut wawancara yang dilakukan penulis dengan bidang Kurikulum (Basuki, 2016) maka dapat disimpulkan faktor-faktor penghambat implementasi RPP di SDN Semangat Dalam 2 sebagai berikut:

1) Alokasi waktu merupakan hal yang sangat penting dalam hal pelaksanaan proses pembelajaran, maka jika waktu pembelajaran tidak maksimal hal tersebut akan berimbas 
Jurnal Manajemen Pendidikan

FKIP Universitas Lambung Mangkurat

6 April 2020

terhadap pendekatan yang

digunakan. Dalam hal ini guru

sebagai pelaksana dalam

implementasi RPP pada anak

ABK, ini menjadi kendalanya

karena kurangnya waktu yang

dibutuhkan dalam melakukan

proses pengamatan pada anak

dalamproses 
pembelajaran karena ketika memberi tugas atau latihan kepada anak ABK seorang guru tidak boleh memaksakan harus selesai berdasarkan waktu yang ditentukan, akan tetapi gurulah yang harus menyesuaikan waktu pada anak ABK tersebut.

2) Sarana dan Prasarana. Sarana dan prasaranan pendidikan inklusif adalah perangkat keras maupun perangkat lunak yang dipergunakan untuk menunjang keberhasilan pelaksanaan pendidikan inklusif pada satuan pendidikan tertentu. Pada hakikatnya semua sarana dan prasarana pendidikan pada satuan pendidikan tertentu itu dapat dipergunakan dalam penyelenggaraan pendidikan inklusi, tetapi untuk mengoptimalkan proses pembelajaran perlu dilengkapi asesibilitas bagi kelancaran mobilisasi anak berkebutuhan khusus, serta media pembelajaran yang sesuai dengan kebutuhan anak berkebutuhankhusus.

3) Terkendala oleh guru karena dalam implementasi RPP guru dituntut untuk lebih dapat memahami dan menyesuaikan diri terhadap setiap anak dengan bermacam-macam sikap dan kebutuhan anak-anak yang dihadapinya. Hal tersebut dikarenakan di SDN Semangat Dalam sudah menerapkan sistem kelas "nitrogen" (Menggabungkan antara anakanak ABK yang memiliki IQ dibawah rata-rata, anak lambat dalam penangkap pelajaran [slowlearner], anak tunalaras, dan anak ABK lainnya, dengan anak normal lainnya dalam kelas regular), maka dalam proses pembelajaran di kelas guru mengalami kesulitan dalam menyesuaikan dan menghadapi perbedaan sikap anakanak tersebut karena dalam kelas nitrogren tentunya guru dituntut untuk bisa memahami dan menyesuaikan segala sesuatu berdasarkan kemampuan dan kebutuhan setiap anak/siswa. Kemudian, masih kurangnya pengetahuan guru dalam masalah penangan anak ABK di sekolahinklusi. 
Jurnal Manajemen Pendidikan

FKIP Universitas Lambung Mangkurat

6 April 2020

4) Kesalahan asuh orang tua yang terlalu memanjakan anak dan perlakuan orang tua yang tidak pas terhadap anak juga bisa menyebabkan anak bertingkahaneh. 


\section{SIMPULAN DAN SARAN}

\section{Simpulan}

Berdasarkan hasil temuan dan analisis data sebagaimana fokus penelitian, maka diperoleh beberapa kesimpulan sebagai berikut:

Salah satu langkah dalam memastikan bahwa RPP yang dimodifikasi sesuai dengan kekhususan peserta didik maka sekolah menggunakan cara tersendiri. Cara tersebut adalah dengan membuat tim khusus dalam memodifikasi RPP. Tim khusus ini terdiri dari para GPK dan guru pelajaran tertentu.

1) TujuanPembelajaran

Berdasarkan dari hasil wawancara yang telah dilakukan, dari penjelasan yang telah disampaikan bahwa tujuan pembelajaran dirumuskan berdasarkan KD (kompetensi dasar) yang dapat diamati dan diukur. Kemudian tujuan pembelajaran ini memuat kemampuan atau kompetensi yang diharapkan dari peserta didik.

2) MateriPembelajaran

Berdasarkan dari hasil wawancara yang telah dilakukan, dari penjelasan yang telah disampaikan bahwa RPP yang disusun oleh guru mengacu

kepada kurikulum 2013, yang mana dalam perencanaan RPP di modifikasi agar peserta didik anak berkebutuhan khusus dapat mengikuti kegiatan pembelajaran dengan materi yang telah dimodifikasi sedemikian rupa untuk ketercapaiannya kompetensi.

3) Penggunaan MetodePembelajaran Berdasarkan dari hasil wawancara yang telah dilakukan, dari penjelasan yang telah disampaikan bahwa penggunaan metode pembelajaran memiliki beberapa macam metode yang dilakukan sesuai dengan karakter dari anak tersebut seperti pemberian metode bimbingan penuh, praktek, dan ceramah.

\section{4) Penilaian/Evaluasi}

Berdasarkan dari hasil wawancara yang telah dilakukan, dari penjelasan yang telah disampaikan bahwa dalam penilaian hasil belajar anak menyesuaikan dengan kemampuan anak, misalnya saja anak yang tidak bisa membaca dan menulis maka evaluasi yang dilakukan guru yaitu dengan nilai praktek, perilaku respon terhadap perintah dan jika anak 
tersebut akan berimbas terhadap

bisa membaca dan menulis, evaluasi

yang dilakukan yaitu dengan

menyesuaikan kemampuan anak yang

mana yang mudah dipahami anak.

Adapun faktor pendukung dan penghambat dalam pelaksanaannya, diantaranya sebagai berikut:

\section{Faktor pendukung}

1) Pengalaman profesionalguru

2) Kemampuan guru dalam mengembangkan program tahunan dansemester

3) Mengembangkan silabus dan modifikasi RPP serta menciptakan lingkungan yang kondusif dalam pelaksanaanpembelajaran

4) Tersedianya media pendukung misalnya melalui internet, guru dapat dengan mudah memahami RPP bernilai-nilai karakter dalam proses pembelajaran, sebagian besar guru yang sudah bisa membuat sendiri RPP bernilai-nilai karakter tidak segan untuk membantu guru yang belum memahami RPP bernilai-nilai berkarakterbangsa.

\section{Faktor penghambat}

1) Alokasi waktu merupakan hal yang sangat penting dalam hal pelaksanaan proses pembelajaran, maka jika waktu pembelajaran tidak maksimal hal pendekatan yang digunakan. Dalam hal ini guru sebagai pelaksana dalam implementasi RPP pada anak ABK, ini menjadi kendalanya karena kurangnya waktu yang dibutuhkan dalam melakukan proses pengamatan pada anak dalam proses pembelajaran karena ketika memberi tugas atau latihan kepada anak ABK seorang guru tidak boleh memaksakan harus selesai berdasarkan waktu yang ditentukan, akan tetapi gurulah yang harus menyesuaikan waktu pada anak ABKtersebut.

2) Sarana dan Prasarana. Sarana dan prasaranan pendidikan inklusif adalah perangkat keras maupun perangkat lunak yang dipergunakan untuk menunjang keberhasilan pelaksanaan pendidikan inklusif pada satuan pendidikan tertentu. Pada hakikatnya semua sarana dan prasarana pendidikan pada satuan pendidikan tertentu itu dapat dipergunakan dalam penyelenggaraan pendidikan inklusi, tetapi untuk mengoptimalkan proses pembelajaran perlu dilengkapi asesibilitas bagi kelancaran mobilisasi anak berkebutuhan khusus, serta media pembelajaran yang sesuai dengan kebutuhan anak berkebutuhankhusus. 
3) Terkendala oleh guru karena dalam implementasi RPP guru dituntut untuk lebih dapat memahami dan

\section{Saran}

menyesuaikan diri terhadap setiap anak dengan bermacam-macam sikap dan kebutuhan anak-anak yang dihadapinya. Hal tersebut dikarenakan di SDN Semangat Dalam sudah menerapkan sistem kelas "nitrogen" (Menggabungkan antara anak-anak ABK yang memiliki IQ dibawah ratarata, anak lambat dalam penangkap pelajaran [slowlearner], anak tunalaras, dan anak ABK lainnya, dengan anak normal lainnya dalam kelas regular), maka dalam proses pembelajaran di kelas guru mengalami kesulitan dalam menyesuaikan dan menghadapi perbedaan sikap anakanak tersebut karena dalam kelas nitrogren tentunya guru dituntut untuk bisa memahami dan menyesuaikan segala sesuatu berdasarkan kemampuan dan kebutuhan setiap anak/siswa. Kemudian, masih kurangnya pengetahuan guru dalam masalah penangan anak $\mathrm{ABK}$ di sekolahinklusi.

4) Kesalahan asuh orang tua yang terlalu memanjakan anak dan perlakuan orang tua yang tidak pas terhadap anak juga bisa menyebabkan anak 
Jurnal Manajemen Pendidikan

FKIP Universitas Lambung Mangkurat

6 April 2020

\section{REFRENSI}

Amka. (2020). Manajemen Sarana Sekolah Penyelenggara Inklusi. Sidoarjo: Nizamia Learning Center

Amka. (2019). Pendidikan Inklusi Bagi Siswa Berkebutuhan Khusus Di Kalimantan Selatan. Jurnal Pendidikan Dan Kebudayaan, 8689

Andriani, N. (2016). Implementasi Rencana pelaksanaan Pembelajaran (RPP) yang Berkarakter pada Mata Pelajaran IPS Terpadu. 437.

Fitria, R. (2012, Januari). Proses Pembelajaran Dalam Setting Inklusi Di Sekolah Dasar, I.

Kunandar. 2011. Guru Profesional (Implementasi Kurikulum Tingkat Satuan Pendidikan dan Sukses dalam Sertifikasi Guru). Jakarta: Raja Grafindo Persada

Mayasari. (2016). Implementasi Kurikulum 2013 pada Anak Berkebutuhan Khusus (ABK) : Studi Kasus SD Muhammadiyah Sapen Yogyakarta. Journal of Disability Studies , 1314.

Nurhayati. 2012. Petunjuk Pelaksanaan Pembuatan RPP Terintegrasi TIK. Jakarta: PUSTEKOM

Pratiwi, J. C. (2015). Sekolah Inklusi Untuk Anak Berkebutuhan Khusus: Tanggapan Terhadap Tantangan Kedepannya. 327.

Setiawan, A. (2016). Pelaksanaan Kurikulum Modifikasi di Sekolah Inklusif. -, 23.

Sholawati, S. A. (2019). Manejemen Pembelajaran Pendidikan Inklusi pada Anak Berkebutuhan Khusus di SDN Kalirungut-1 Surabaya. Jurnal Pendidikan Madrasah Ibtidayah, 45.

Widyawati, R. (2017). Evaluasi

Pelaksanaan Program Inklusi

Sekolah Dasar. Jurnal

Manajaemen Pendidikan ,116.

Jakarta: Depdiknas. 

